\title{
The effects of forest fragmentation on genetic variation in Acer saccharum Marsh. (sugar maple) populations
}

\author{
A. G. YOUNG*†, H. G. MERRIAM \& S. I. WARWICK $\ddagger$ \\ Ottawa-Carleton Institute of Biology, Department of Biology, Carleton University, Ottawa, Ontario, Canada K1S $5 B 6$ and \\ $¥$ Centre for Land and Biological Resources Research, Agriculture Canada, Ottawa, Ontario, Canada K1A OC6
}

\begin{abstract}
To investigate the effects of forest fragmentation on genetic variation in Acer saccharum Marsh. (Aceraceae) populations, allozyme variation in eight populations in fragmented forest patches was compared to variation in eight population samples from extensive continuous forest. Contrary to theoretical predictions, increased genetic drift and inbreeding have not led to reduced withinindividual or within-population genetic variation in patch populations. Polymorphism and individual heterozygosity were slightly higher in patch than continuous forest populations. However, overall, founder effects may have resulted in the loss of six alleles in the fragmented forest system. Maintenance of genetic variation in patch populations may be because of the limited number of generations since fragmentation occurred, or because populations in patches have not been reduced below the size of normal breeding associations for $A$. saccharum. Comparison of the distribution of alleles among populations, between patch and continuous forest, suggests that the higher genetic variation in patch populations may be the result of increased interpopulation gene flow.
\end{abstract}

Keywords: Acer saccharum, allozyme, forest fragmentation, gene flow, genetic variation, population.

\section{Introduction}

Over the past $100-200$ years habitat fragmentation, resulting from human modification of the environment, has affected many ecosystems all over the world, e.g. forest (Harris, 1984), grassland (Lord \& Norton, 1990), scrubland (Margules \& Nicholls, 1987) and prairie (Wilcove, 1987). Habitat fragmentation, the breaking up of continuous habitat into smaller habitat patches, has considerable potential to rapidly and severely reduce population size and increase population isolation.

Studies of natural plant populations have shown that population size is an important factor in determining the amount of genetic variation maintained within sexual populations and how it is distributed among individuals. Using allozyme data Moran \& Hopper (1983), McClenaghan \& Beauchamp (1986), Sampson et al. (1988) and Billington (1991), have shown that small

*Correspondence.

$\dagger$ Present address: CSIRO, Division of Plant Industry, GPO Box 1600, Canberra, ACT 2601, Australia. populations exhibit less single locus variation, both within populations and individuals, than larger populations. Polans \& Allard (1989) obtained similar results in an experimental study with ryegrass, in which they manipulated population size to investigate the genetic effects of population bottlenecks. They demonstrated that reduction in population size resulted in reduced single locus allozyme and multi-locus quantitative morphological variation. In all of these examples reduced genetic variation in small populations may be attributed to founder effects, increased inbreeding and/ or genetic drift.

Recently, Wilcove (1987), Templeton et al. (1990), Billington (1991) and Saunders et al. (1991) have all suggested that reduced population size and increased isolation, associated with habitat fragmentation, may cause a reduction in genetic variation in habitat patch populations. This may directly affect the short-term ecological success of patch populations through inbreeding depression. It may also influence the evolutionary potential of populations and species, if genetic variation is reduced so much that populations can no longer respond to changing environments through 
selection. It is also possible that increased population isolation, resulting from habitat fragmentation, may lead to increased genetic differentiation among habitat patch populations.

The objective of this study was to investigate empirically the effects of habitat fragmentation, in this case forest fragmentation, on genetic variation in Acer saccharum Marsh. (sugar maple). Specifically, the hypotheses that forest patch populations of $A$. saccharum have less genetic variation than more continuous forest populations, owing to founder effects, increased genetic drift and/or inbreeding, and that patch populations are more genetically differentiated, because of increased population isolation, were tested.

\section{Methods}

\section{Study species}

Acer saccharum (Aceraceae) is a common tree throughout the deciduous forests of south-eastern Canada and the north-eastern United States, occurring naturally in large populations. It is shade tolerant (Logan, 1965; Forcier, 1973), capable of sustained population regeneration (Nigh et al., 1985) and lives for 200-300 years (Ledig \& Korbobo, 1983). Acer saccharum maintains no seed bank (Marquis, 1975). Plants may reach reproductive maturity as early as 40 years of age (Westman, 1968). Acer saccharum is monoecious and self-compatible, though seed set from selfed flowers is poor (Gabriel, 1967) and selfing is restricted by incomplete dichogamy (Gabriel, 1968). Although it is thought to be both insect and wind pollinated, experimental data suggest that wind is the primary pollen vector (Gabriel \& Garrett, 1984). Seeds are wind dispersed. The species is diploid $(2 n=26)$ throughout its geographic range (Kriebel, 1957). Observed levels of allozyme variation within and between populations are within expectations for a primarily outbreeding angiosperm tree (Perry \& Knowles, 1989).

\section{Experimental design and study populations}

To assess the effects of forest fragmentation, genetic (allozyme) variation in eight $A$. saccharum populations, in fragmented forest patches, was compared with variation in eight control populations, within relatively continuous $A$. saccharum dominated forest. This approach assumes that the current genetic variation in large $A$. saccharum populations represents the genetic variation of the prefragmentation populations, from which present patch populations were derived.
Forest patch populations (patches) were located around North Gower and Manotick, south of Ottawa, in eastern Ontario, Canada: $45^{\circ} 10.4^{\prime} \mathrm{N}, 75^{\circ} 40.6^{\prime} \mathrm{W}$ (Fig. 1). Patches were 1.4-6.3 ha (Table 4) and were part of a mosaic of forest patches separated by intervening agricultural land. Forest patches were created 100-200 years ago when the forest in this area was cleared for crops and pasture (Middleton, 1982). Each patch population was at least $400 \mathrm{~m}$ from the nearest A. saccharum population and patches were spread over a total area of approximately $400 \mathrm{~km}^{2}$, which encompassed many other similar forest patches containing A. saccharum. All eight forest patches showed evidence of human disturbance, e.g. tree cutting. Control populations (controls) were population samples located within extensive A. saccharum dominated forest in Gatineau Park, Québec: $45^{\circ} 35.0^{\prime} \mathrm{N}$, $75^{\circ} 55.4^{\prime} \mathrm{W}$ (Fig. 1), $50 \mathrm{~km}$ north of the patch populations. Controls were also spread over approximately $400 \mathrm{~km}^{2}$. Within patch and control forest, A. saccharum was primarily associated with Fagus grandifolia Ehrh. and Tilia americana L. Forest patches also had a significant Fraxinus americana L. component and some of the control forest contained Quercus rubra $\mathrm{L}$.

\section{Genetic data}

Genetic variation was assayed in the first-year seedlings of each of the 16 populations. This is the generation in which any genetic changes that have occurred since forest fragmentation should be most obvious. Within each population 50 seedlings were sampled randomly from a 1 ha square quadrat. Seedlings were removed intact, transplanted into pots, and maintained in a greenhouse for the duration of the study.

Horizontal starch gel electrophoresis was used to obtain allozyme data for all seedlings. Mature leaf tissue $\left(1.5-2 \mathrm{~cm}^{2}\right)$ was removed from each plant and freshly ground $(<5 \mathrm{~h})$ in a mortar and pestle at $4^{\circ} \mathrm{C}$, in $1.5 \mathrm{ml}$ of extraction buffer: 2 per cent tergitol $15-\mathrm{S}-9,2$ per cent polyethyleneglycol $20 \mathrm{M}, 8$ per cent polyvinyl-

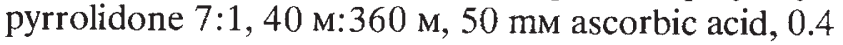
$\mathrm{mm}$ nicotinamide adenine dinucleotide, 0.1 per cent bovine serum albumin, $0.2 \mathrm{~mm}$ pyridoxal 5 '-phosphate, $0.3 \mathrm{~m}$ sucrose, $12 \mathrm{~mm}$ cysteine- $\mathrm{HCl}$ and $0.66 \mathrm{ml} \beta$ mercaptoethanol (Cheliak \& Pitel, 1984). Samples were frozen in $2 \mathrm{ml}$ microcentrifuge tubes at $-80^{\circ} \mathrm{C}$ until electrophoresis. Frozen samples were thawed to an icy slurry and absorbed onto $3 \times 14 \mathrm{~mm}$ filter paper wicks for introduction into starch gels. Starch gels were 10.5 per cent w/v and $1 \mathrm{~cm}$ thick. Four gel/electrode buffer systems, ranging from $p \mathrm{H} 5.7$ to $p \mathrm{H} \mathrm{8.8,} \mathrm{were}$ used (Table 1). Gels were run until a bromophenol blue marker had migrated $1 \mathrm{~cm}$. Wicks were removed and 
Fig. 1 Locations of eight forest patch - $(\mathrm{a}-\mathrm{h})$ and eight control $(\mathrm{A}-\mathrm{H})$ populations of $A$. saccharum.

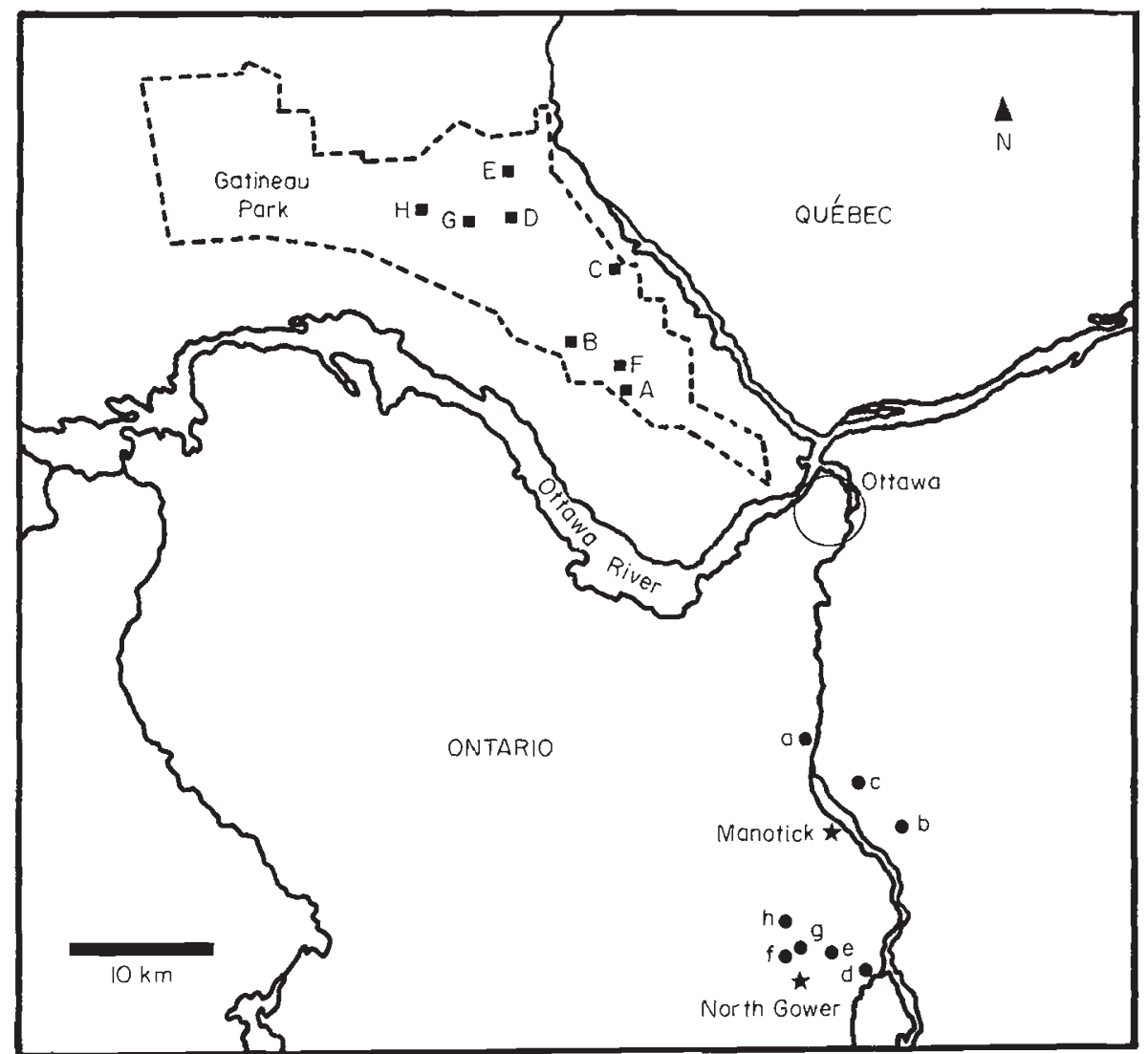

Table 1 Electrophoresis buffer systems and enzymes

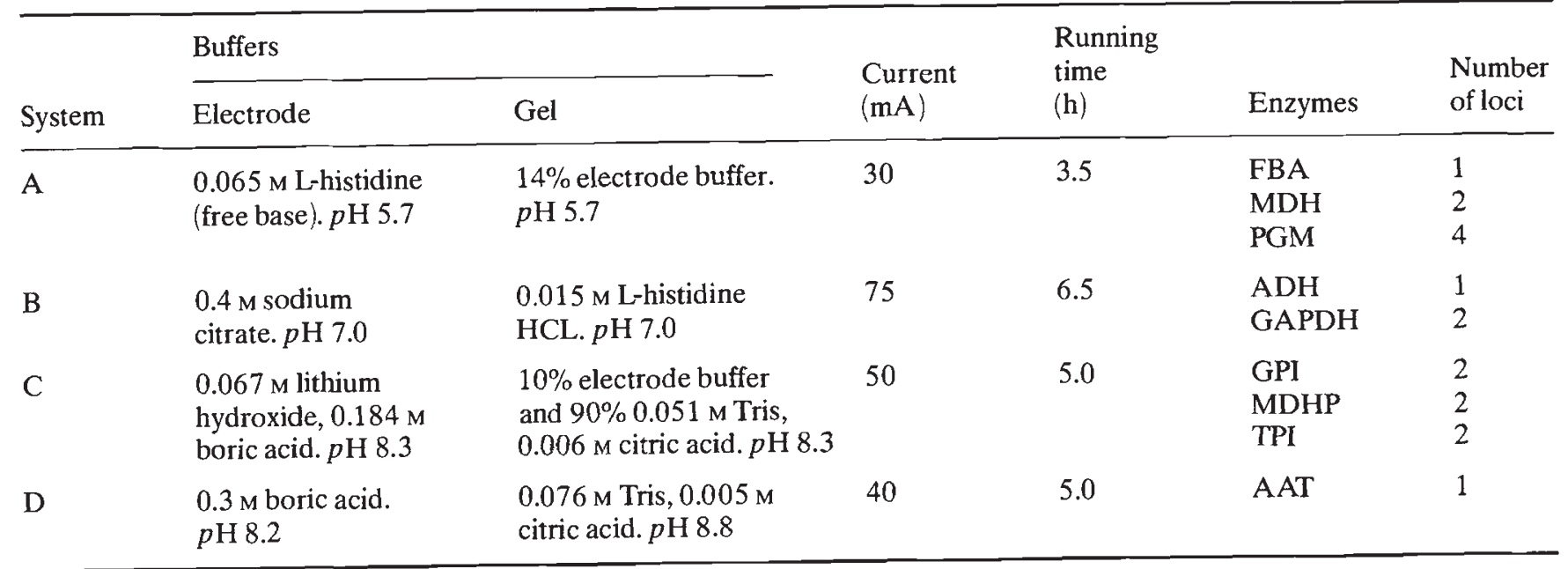

gels were then run until the marker reached $10 \mathrm{~cm}$ $(3.5-6.5 \mathrm{~h})$. All gels were run at constant current (Table 1) at $4^{\circ} \mathrm{C}$. Gels were sliced horizontally into $2 \mathrm{~mm}$ slices and stained for enzymes following Weeden \& Wendel (1989).

Seventeen putative allozyme loci for nine enzymes were resolved clearly and consistently (Table 1). These were: alcohol dehydrogenase $(\mathrm{ADH})$ E.C. 1.1.1.1 (1 locus), aspartate aminotransferase (AAT) E.C. 2.6.1.1 (1 locus), fructose-bisphosphate aldolase (FBA) E.C. 4.1.2.13 (1 locus), glucose-6-phosphate isomerase (GPI) E.C. 5.3.1.9 (2 loci), glyceraldehyde-3-phosphate dehydrogenase (GAPDH) E.C. 1.2.1.12 (2 loci), malate dehydrogenase (MDH) E.C. 1.1.1.37 (NAD) (2 loci), 
malate dehydrogenase (MDHP) E.C. 1.1.1.40 (NADP) (2 loci), phosphoglucomutase (PGM) E.C. 5.4.2.2 (4 loci) and triose-phosphate isomerase (TPI) E.C. 5.3.1.1 (2 loci). When there were several loci for a single enzyme they were numbered in decreasing order of anodal mobility. Alleles at a locus were identified by their mobility relative to the migration of the bromophenol blue marker $\left(\mathrm{R}_{\mathrm{f}}\right)$. Phosphoglucomutase exhibited four loci rather than the more usual two (Weeden \& Wendel, 1989). Alleles Pgm-1: 0.375, 0.320 and $P g m$-4: 0.205 were excluded from the data analysis. These alleles overlapped alleles from $P g m-2$ and Pgm-3, respectively, so that, given the enzyme's monomeric structure, heterozygotes involving these alleles had to be identified by relative band intensity and thus proved unsatisfactory. Mendelian inheritance of Fba-1, Aat-2, Gpi-2 and Mdh-1 has been verified for $A$. saccharum by Lelliot (1987). It was assumed for the other polymorphic loci, based on concordance between observed and expected banding patterns of putative heterozygotes, given previously suggested enzyme subunit structures (Weeden \& Wendel, 1989; Kephart, 1990).

\section{Reproductive individuals}

The density of reproductive individuals was estimated for all populations. Within each 1 ha quadrat, 6-10 sampling plots, each $20 \times 20 \mathrm{~m}$, were placed randomly and all reproductively mature individuals were counted. These were defined as trees exhibiting flowers and/or seed, or $>20 \mathrm{~cm}$ diameter at $1 \mathrm{~m}$ in height. Mean densities were used to estimate reproductive population sizes for each patch population.

\section{Pollen movement}

To assess the potential for pollen movement among patch populations pollen trapping was conducted around patch ' $a$ '. This population was surrounded by pasture and was $>1 \mathrm{~km}$ from the nearest $A$. saccharum population. Traps were set along four transects (east, east south-east, south south-east, south) in 1989 and five transects (north-east, east, south-east, south, west) in 1991. Transects were perpendicular to the forest margin with traps every $20 \mathrm{~m}$, from $20 \mathrm{~m}$ within the forest to $460-540 \mathrm{~m}$ beyond the forest. Pollen traps consisted of a microscope slide smeared with petroleum gel, placed in an inverted petri dish lid and mounted $1 \mathrm{~m}$ above the ground on a steel rod. Trapping was conducted from 1 to 28 May, 1989 , and 1 to 21 May, 1990. Early May is the main period of pollen release for $A$. saccharum in the Ottawa region (Bassett, 1969). Traps were replaced every week, or after each rain. Pollen density was estimated for each slide from a $1 \mathrm{~cm}^{2} 25$ point sampling grid, giving a total count area of $44 \mathrm{~mm}^{2}$ per slide.

\section{Data analysis}

Genetic variation and mating system. Several measures of genetic variation were estimated for each population: polymorphism $(P)$ - the percentage of loci that are polymorphic, allelic diversity $(A)$ - the number of alleles per locus and individual heterozygosity $\left(H_{\mathrm{I}}\right)-$ the proportion of loci heterozygous per individual. Polymorphism (arcsine transformed data) and allelic diversity were compared between patches and controls by $t$-tests. Individual heterozygosity (arcsine transformed data) was compared using nested analysis of variance, with populations as subgroups.

To examine population deviation from random mating inbreeding coefficients $\left(F_{\text {IS }}\right)$ (Wright, 1965, 1978), weighted by expected heterozygosity, were estimated. The overall goodness-of-fit of observed genotype frequencies to those expected under Hardy-Weinberg equilibrium was assessed using Chisquare tests for each locus, with Bonferroni correction for multiple tests (Weir, 1990). For genotypes that involved rare alleles, and therefore had low expected values, alleles were pooled to create two classes, the most common allele and all other alleles. If expected values were still below five, Fisher's exact tests were used. Least-squares linear regression was used to provide a conservative test of the significance of the relationship between mean density of reproductive individuals and mean inbreeding coefficient.

Genetic differentiation. Several measures of genetic differentiation were estimated separately for patch and control populations. $G$-tests were used to test for differences in allele frequencies at each locus among populations. When allele frequencies were low, Monte Carlo simulations were used to provide estimates of the significance of $G$ using an algorithm devised by Roff \& Bentzen (1989). Mean fixation coefficients $\left(F_{\mathrm{ST}}\right)$ (Wright, 1965, 1978) were calculated, weighted by expected heterozygosity. Nei's minimum genetic distances $\left(D_{\mathrm{m}}\right)$ (Nei, 1987) were estimated for all population comparisons and averaged within and between patches and controls.

Reproductive individuals. Nested analysis of variance was used to compare the density of reproductive individuals between patches and controls, using populations as subgroups.

Unless otherwise stated all statistical procedures followed Sokal \& Rohlf (1981). 


\section{Results}

\section{Genetic variation and mating system}

Thirteen of the 17 loci exhibited allelic variation. A total of 58 alleles were observed in the 16 populations. Population allele frequencies, polymorphism, allelic diversity and individual heterozygosity estimates are presented in Appendix I. Locus and population inbreeding coefficients are presented in Appendix II.

Genetic variation and mating system summary statistics are presented in Table 2. A total of 48 alleles were observed in the eight patch populations, compared with 54 alleles in control populations. Mean polymorphism was slightly higher in patches than in controls $(p=0.065)$. There was no significant difference in mean allelic diversity. On average, patches had a larger proportion (mean $=0.81$, standard error, S.E. $=0.01)$ of their allele pool than controls $($ mean $=0.69$, S.E. $=0.02)(p=0.007)$. Of the 44 alleles common to both patch and control populations, 11 (Aat-2: 0.400, 0.170, Gpi-2: 0.345, Mdhp-4: 0.230, Pgm-1: 0.390, Pgm-2: 0.410, 0.325, Pgm-3: 0.170, Pgm-4: 0.155, 0.135, Tpi-1: 0.470) were distributed more widely among patches than controls. The mean increase in spread for these alleles was 2.1 populations $($ S.E. $=0.3)$. Only six alleles $(G p i-2: 0.430,0.270$, Pgm-2: 0.315, Pgm-3: 0.235, Pgm-4: 0.185, 0.140) were distributed more widely among controls than among patches. The mean increase in spread for these alleles was 1.2 populations (S.E. $=0.2$ ). Mean individual heterozygosity was slightly higher in patches than in control populations $(p=0.087)$. There was no significant difference in interpopulation variation in individual heterozygosity between patches and controls.

Based on locus tests, two patch populations (d, e) and one control population $(F)$ deviated significantly from Hardy-Weinberg equilibrium (Appendix II). All exhibited a deficit of heterozygotes. Mean inbreeding coefficients were very similar for patches and controls (Table 2), though coefficients varied widely among loci within populations and among populations within patch and control groups (Appendix II). There was no significant relationship between the mean density of reproductive individuals within a population and mean inbreeding coefficient.

\section{Genetic differentiation}

Differences in allele frequencies occurred at six loci (Aat-2, Fba-1, Gpi-2, Pgm-1, Pgm-2, Pgm-4) among patch populations and at four loci (Aat-2, Mdhp-2, Pgm-2, Pgm-4) among control populations (Appendix I). Locus and mean fixation coefficients are presented in Appendix II. The overall fixation coefficient for patches was $F_{\mathrm{ST}}=0.019$, very similar to the $F_{\mathrm{ST}}=0.017$ for controls, indicating that, in both patches and controls, less than 2 per cent of the observed variation was attributable to differentiation among populations. Nei's minimum genetic distances were also low, and very similar, for patches and controls (Table 3 ).

\section{Reproductive individuals}

The mean density of reproductive individuals in patches was $5.2($ S.E. $=0.9)$ individuals per $400 \mathrm{~m}^{2}$, slightly lower than in controls: mean $=7.1($ S.E. $=0.3)$ individuals per $400 \mathrm{~m}^{2}(p=0.083)$. Patches had more among-population variation in density than controls $(p=0.001)$. Estimates of reproductive population sizes for patches are presented in Table 4 .

\section{Pollen movement}

A sample of the pollen data from 1989 and 1990, for patch population ' $a$ ', is presented in Fig. 2. Comparison of pollen density along the east south-east and east

Table 2 Genetic variation and mating system summary statistics for $A$. saccharum patch and control populations

\begin{tabular}{llll}
\hline & $\begin{array}{l}\text { Patch } \\
\text { populations }\end{array}$ & $\begin{array}{l}\text { Control } \\
\text { populations }\end{array}$ & $p$ \\
\hline Total alleles & 48 & 54 & \\
Mean polymorphism $(P)$ & $58.8(1.9)$ & $53.7(1.7)$ & 0.065 \\
$\begin{array}{l}\text { Mean allelic diversity }(A) \\
\text { Mean individual }\end{array}$ & $2.10(0.04)$ & $2.03(0.06)$ & 0.087 \\
$\quad$ heterozygosity $\left(H_{\mathrm{I}}\right)$ & $0.121(0.006)$ & $0.109(0.004)$ & \\
$\begin{array}{l}\text { Mean inbreeding } \\
\quad \text { coefficient }\left(F_{\text {IS }}\right)\end{array}$ & 0.050 & 0.073 & \\
\hline
\end{tabular}

$F_{\text {IS }}$ is weighted by expected heterozygosity. $n=8$. () Standard error. 
transects for 1989 (Fig. 2a and b) shows that there was directional variation in pollen rain around the source population. Comparison of data from 1989 and 1990 for the east transect (Fig. 2b and c) shows that there was also year to year variation in pollen rain. Compared with 1989, there was little pollen rain in 1990 and very few flowers were observed on trees. However, pollen was still distributed along all transects.

\section{Discussion}

If the original assumption of this study is correct, i.e. that $A$. saccharum populations in continuous forest are representative of prefragmentation populations, then comparison of polymorphism, allelic diversity and individual heterozygosity between patch and control populations shows that forest fragmentation has not led to the expected loss of genetic variation at the population or individual level. Furthermore, there has been no apparent increase in inbreeding in patches. Similarly, based on genetic distances, fixation coefficients and allele frequency comparisons, the amount of differentiation among patch populations has not

Table 3 Mean (range in brackets) Nei's minimum genetic distances $\left(D_{\mathrm{m}}\right)$ among $A$. saccharum patch and control populations

\begin{tabular}{lll}
\hline & Patch populations & Control populations \\
\hline Patch & 0.003 & \\
$\quad$ populations & $(0.001-0.006)$ & \\
Control & 0.003 & 0.002 \\
populations & $(0.001-0.005)$ & $(0.001-0.004)$ \\
\hline
\end{tabular}

Table 4 Patch areas, densities of reproductive individuals (inds) and estimates of reproductive population size for $A$. saccharum patch populations

\begin{tabular}{llll}
\hline & & $\begin{array}{l}\text { Mean density } \\
\text { reproductive } \\
\text { individuals } \\
\text { Patch } \\
\text { population }\end{array}$ & $\begin{array}{l}\text { Estimated } \\
\text { reproductive } \\
\text { population }\end{array}$ \\
\hline a & Area (ha) & $\begin{array}{l}\left.\text { (inds per } 400 \mathrm{~m}^{2}\right) \\
\text { size (inds) }\end{array}$ \\
b & 6.3 & $4.1(0.7)$ & 646 \\
c & 1.8 & $3.0(1.2)$ & 135 \\
d & 1.6 & $5.9(1.2)$ & 236 \\
e & 2.0 & $8.3(1.3)$ & 415 \\
$\mathrm{f}$ & 1.8 & $2.0(0.5)$ & 90 \\
$\mathrm{~g}$ & 1.5 & $8.0(1.0)$ & 300 \\
$\mathrm{~h}$ & 1.5 & $7.2(0.9)$ & 270 \\
\hline
\end{tabular}

() Standard error. increased. Forest fragmentation does appear, however, to have affected the overall genetic variation of the forest system, with the eight patch populations having six fewer alleles in total than the eight control populations.

One possible explanation for the maintenance of genetic variation in patch populations is that there has not been enough time since fragmentation for processes such as genetic drift and inbreeding to erode genetic variation, or for mutation and genetic drift to generate among population differences. Given a minimum age for $A$. saccharum of 40 years at reproductive maturity, and 100-200 years since the forest was cleared, patch populations may have only gone through 2-5 generations in their present reduced state. It may also be that, from a genetic perspective, population size has not been affected much by forest fragmentation. Reproductive populations found in forest patches

(a) East south-eost transect 1989
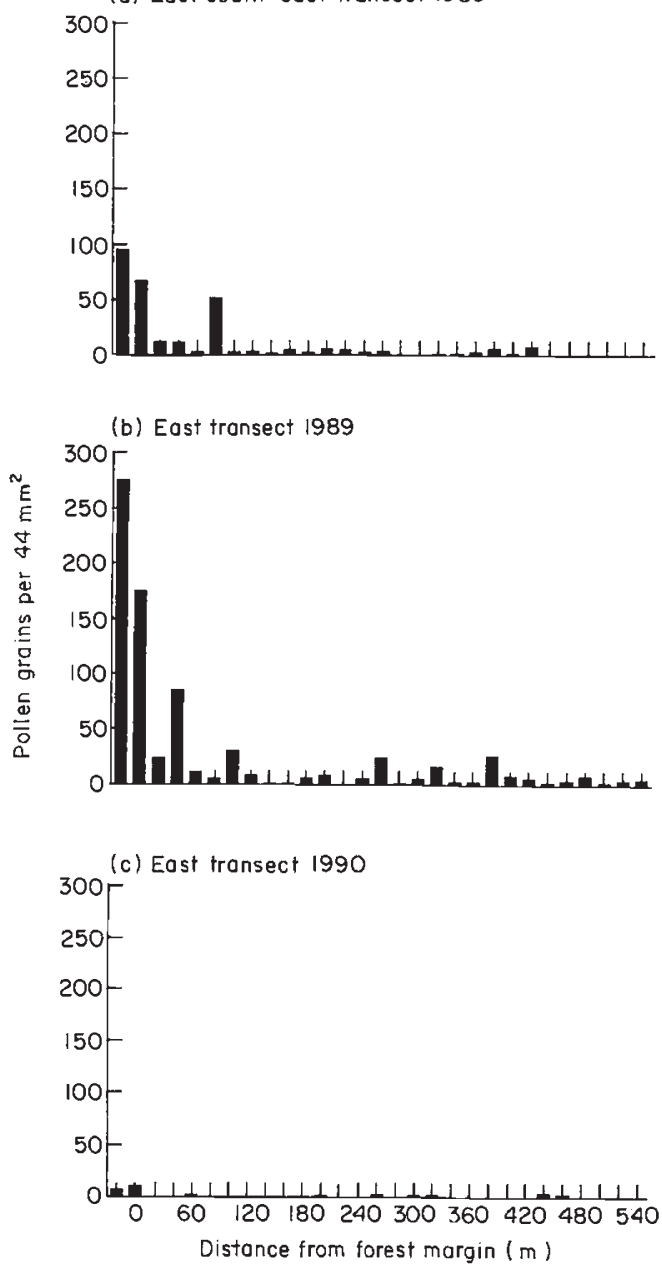

Fig. 2 Pollen rain around patch population ' $a$ ' for May 1-28, 1989 and May 1-21, 1990. (a) East south-east transect 1989. (b) East transect 1989. (c) East transect 1990. 
(90-646 individuals, Table 4) may be larger than normal breeding associations (genetic neighbourhoods - Wright, 1946) occurring within continuous forest. If this is the case, rates of genetic drift and inbreeding would not be expected to increase in patch populations.

However, these explanations cannot account for polymorphism and heterozygosity being higher in patch populations than controls. This suggests that within-population and within-individual genetic variation in patch populations has increased since fragmentation, indicating that other processes may be important in determining genetic variation in patches. Patch populations had higher polymorphism than controls because, on average, they had a larger share of their allele pool. Together with the greater spread of several alleles among patch populations, this suggests that interpopulation gene flow is higher among patches than controls. Modelling data on A. saccharum seed dispersal (Green, 1980; Sharpe \& Fields, 1982; Guries \& Nordheim, 1984; Dirschl, 1988) and indirect observations of dispersal by examination of seedling distributions (Benzie, 1959; Westman, 1968; Johnson, 1988) show that seed dispersal is unlikely to account for gene flow among patch populations over commonly encountered interpatch distances of hundreds of metres. However, the pollen trapping data show that wind dispersal of pollen could provide a gene flow vector over distances of up to $400 \mathrm{~m}$ across pasture fields. Such pollen mediated gene flow among patches might be greater than among populations in continuous forest, where wind speed is lower, pollen is lost to impaction on trees and effective gene flow may be reduced by pollen dilution. If there is more gene flow among patch populations, patches should be more genetically homogeneous than controls. Genetic differentiation results show they were not, suggesting that the increase in gene flow is small, or possibly that gene flow is intermittent. This may be the very type of gene flow that wind dispersal of pollen provides, given the large year to year variation observed in pollen rain.

There are several possible explanations for the higher individual heterozygosity in patch populations. The simplest is that increased heterozygosity is a reflection of higher polymorphism. Increased outbreeding in patch populations would also result in higher heterozygosity. Such a shift in mating system might be promoted by the lower densities of reproductive individuals in patch populations, with mating occurring among individuals that are further apart and therefore less likely to be related. However, mean inbreeding coefficients for patch and control populations were similar, and there was no apparent relationship between density of reproductive individuals and inbreeding. Finally, selection may be affecting heterozygosity. For example, data on forest microclimate, from diverse forest ecosystems (Wales, 1967; Kapos, 1989; Young, 1988), have shown that light intensities in small forest patches may be higher than in the interior of continuous forest. Under such conditions there is no advantage to shade tolerance and slow growth: those individuals that dominate and reproduce may simply be those that grow most quickly. In contrast in the continuous forest, where canopy gaps provide the opportunity for rapid growth only irregularly, slow sustained growth may be a more effective strategy for reaching reproductive maturity. Several studies have identified relationships between individual levels of protein heterozygosity and growth rate in tree species, e.g. Mitton \& Grant (1980). Such a relationship for $A$. saccharum would provide a mechanism by which heterozygosity might be selected for in patch populations.

The apparent overall loss of six alleles from the eight patch populations is unlikely to be due to increased genetic drift, if gene flow among patches has increased since forest fragmentation. However, it may be the result of founder events that took place when fragmentation occurred. When the forest was cleared many individuals were removed from between the present forest patches, and some low frequency alleles may not have been included in those that made up the remaining populations. The six alleles $(A d h-1: 0.355, F b a-1$ : $0.230,0.175$, Gpi-2: $0.450,0.435,0.255)$ not present in patch populations all occurred in control populations at low frequencies.

Overall, these results show that forest fragmentation has had an effect on genetic variation in $A$. saccharum populations. Initially founder effects may have played an important role in determining the genetic variation of $A$. saccharum forest patch populations, by reducing the number of alleles available in the fragmented forest system as a whole. However, contrary to theoretical expectations, increased genetic drift and inbreeding have not led to a loss in genetic variation within individuals and populations, and interpopulation genetic differentiation has not increased. This may be because of the limited number of generations since these $A$. saccharum populations were reduced in size, or because, genetically, population size has not been affected much by fragmentation. Both of these possibilities indicate that life history traits of the species, specifically factors such as longevity and breeding structure, are important in determining the effects of habitat fragmentation. However, the apparent increase in genetic variation in patch populations, despite reduced overall allele pool, combined with the increase in spread of alleles among populations, point to other 
factors, specifically increased interpopulation gene flow and possibly changes in selection regime, as being important determinants of genetic variation in $A$. saccharum forest patch populations.

\section{Acknowledgements}

This research was supported by Carleton University, Agriculture Canada, Environment Canada Parks Service (contract to S.I.W. and A.G.Y.) and the Natural Sciences and Engineering Research Council of Canada (operating grant to H.G.M.). Thanks go to Dave Omond for assistance with collection and maintenance of seedlings and with pollen trapping and counting and Lynn Black for advice on electrophoretic techniques.

\section{References}

BASSETT, I. J. 1969. Airborne pollen dispersal of some trees and shrubs in the Ottawa district. Trail and Landscape, 3, 42-44.

BENZIE, J. w. 1959. Sugar maple and yellow birch seed dispersal from a fully stocked stand of mature northern hardwoods in the upper peninsula of Michigan. Lake States Forest Experiment Station Technical Note 561.

BILLiNGTON, H. L. 1991. Effect of population size on genetic variation in a dioecious conifer. Conserv. Biol., 5, 115-119.

CHELIAK, W. M. AND PITEL, J. A. 1984. Techniques for starch gel electrophoresis of enzymes from forest tree species. Canadian Forestry Service Information Report PI-X-42.

DIRSCHL, H. B. 1988. The use of the SEDFAL simulation model to estimate the past seed dispersal of Acer negundo, Acer saccharum, and Fraxinus americana trees in farmland south of Ottawa. B.Sc. Hons Thesis, Carleton University.

FORCIER, L. K. 1973. Seedling pattern and population dynamics, and the reproductive strategies of sugar maple, beech and yellow birch at Hubbard Brook. Ph.D. Thesis, Yale University.

GABRIEL, W. J. 1967. Reproductive behaviour in sugar maple: self-compatibility, cross-compatibility, agamospermy, and agamocarpy. Silvae Genetica, 16, 165-168.

GABRIEL, w. J. 1968. Dichogamy in Acer saccharum. Botanical Gazette, 129, 334-338.

GABRIEL, W. J. AND GARRETT, P. w. 1984. Pollen vectors in sugar maple (Acer saccharum). Can. J. Botany, 62, 2889-2890.

GREEN, D. S. 1980. The terminal velocity and dispersal of spinning samaras. Am. J. Botany, 67, 1218-1224.

GURIES, R. P. AND NORDHEIM, E. V. 1984. Flight characteristics and dispersal potential of maple samaras. Forest Sci., 30, 434-440.

HARRIS, L. D. 1984. The Fragmented Forest: Island Biogeography Theory and the Preservation of Biotic Diversity. The University of Chicago Press, Chicago.

JOHNSON, w. C. 1988. Estimating dispersibility of Acer, Fraxinus and Tilia in fragmented landscapes from patterns of seedling establishment. Landscape Ecol., 1, 175-187.
KAPOS, v. 1989. Effects of isolation on the water status of forest patches in the Brazilian Amazon. J. Trop. Ecol., 5, 173-185.

KEPHART, S. R. 1990. Starch gel electrophoresis of plant isozymes: a comparative analysis of techniques. $A \mathrm{~m} . J$. Botany, 77, 693-712.

KRIEBEL, H. B. 1957. Patterns of genetic variation in sugar maple. Research Bulletin Ohio Agricultural Experimental Station, 791, 1-55.

LEDIG, F. T. AND KORBOвO, D. R. 1983. Adaptation of sugar maple populations along altitudinal gradients: photosynthesis, respiration, and specific leaf weight. Am. J. Botany, 70, 256-265.

LELLIOT, M. 1987. Inheritance of eight enzyme systems in sugar maple (Acer saccharum Marsh.). B.Sc. Hons Thesis, Lakehead University.

LOGAN, K. T. 1965. Growth of tree seedlings as affected by light intensity: I. White Birch, Yellow Birch, Sugar Maple and Silver Maple. Canadian Department of Forestry Publication No. 1121.

LORD, J. M. AND NORTON, D. A. 1990. Scale and the spatial concept of fragmentation. Conserv. Biol., 4, 197-202.

MCCLENAGHAN, L. R. AND BEAUCHAMP, A. C. 1986. Low genetic differentiation among isolated populations of the California fan palm (Washingtonia filifera). Evolution, 40, 315-322.

MARGULES, C. R. AND NICHOLls, A. O. 1987. Assessing the conservation value of remnant habitat 'islands': mallee patches on the western Eyre Peninsula, South Australia. In: Saunders, D. A., Arnold, G. W., Burbidge, A. A. and Hopkins, A. J. M. (eds) Nature Conservation: the Role of Remnants of Native Vegetation, Surrey Beaty and Sons, Chipping Norton, pp. 89-102.

MARQUis, D. A. 1975. Seed storage and germination under northern hardwood forests. Can. J. Forest Res., 5, 478-484.

MIDDLETON, J. D. 1982. On certain spatial characteristics of the distribution of woodland species in farmland. Ph.D. Thesis, Carleton University.

MITTON, J. B. AND GRANT, M. C. 1980. Observations on the ecology and evolution of quaking aspen, Populus tremuloides, in the Colorado front range. Am. J. Botany, 67, 202-209.

MORAN, G. F. AND HOPPER, S. D. 1983. Genetic diversity and the insular population structure of the rare granite rock species, Eucalyptus caesia Benth. Aust. J. Botany, 31, $161-172$.

NE1, M. 1987. Molecular Evolutionary Genetics. Columbia University Press, New York.

NIGH, T. A., PALlardy, S. G. AND GARRETT, H. E. 1985. Sugar maple-environment relationships in the River Hills and Central Ozark Mountains of Missouri. The American Midland Naturalist, 114, 235-251.

PERRY, D. J. AND KNOWLES, P. 1989. Allozyme variation in sugar maple at the northern limit of its range in Ontario, Canada. Can.J. Forest Res., 19, 509-514.

POLANS, N. O. AND ALLARD, R. w. 1989. An experimental evaluation of the recovery potential of ryegrass populations from genetic stress resulting from restriction of population size. Evolution, 43, 1320-1324. 
ROFF, D. A. AND BENTZEN, P. 1989. The statistical analysis of mitochondrial DNA polymorphisms: Chi-square and the problem of small samples. Molec. Biol. Evol., 6, 539-545.

SAMPSON, J. F., HOPPER, S. D. AND JAMES, S. H. 1988. Genetic diversity and the conservation of Eucalyptus crucis Maiden. Aust. J. Botany, 36, 447-460.

SAUNDERS, D. A., HOBBS, R. J. AND MARGULES, C. R. 1991. Biological consequences of ecosystem fragmentation: a review. Conservation Biol., 5, 18-32.

SHARPE, D. M. AND FIELDS, D. E. 1982. Integrating the effects of climate and seed fall velocities on seed dispersal by wind: a model and application. Ecol. Modelling, 17, 297-310.

SOKAL, R. R. AND ROHLF, F. J. 1981. Biometry. Freeman and Company, New York.

TEMPLETON, A. R., SHAW, K., ROUTMAN, E. AND DAVIS, S. K. 1990. The genetic consequences of habitat fragmentation. Annals of the Missouri Botanical Garden, 77, 13-27.

WALES, B. A. 1967. Climate, microclimate and vegetation relationships on north and south forest boundaries in New Jersey. The William L. Hutcheson Memorial Forest Bulletin, 2, 1-60.
WEEDEN, N. F. AND WENDEL, J. F. 1989. Genetics of plant isozymes. In: Soltis, D. E. and Soltis, P. S. (eds) Isozymes in Plant Biology. Dioscorides, Portland, pp. 46-72.

WeIR, B. S. 1990. Genetic Data Analysis. Sinauer Associates, Sunderland.

WESTMAN, w. E. 1968. Invasion of fir forest by sugar maple in Itasca Park, Minnesota. Bulletin of the Torrey Botanical Club, 95, 172-186.

WILCOVE, D. S. 1987. From fragmentation to extinction. Natural Areas J., 7, 23-29.

WRIGHT, s. 1946. Isolation by distance under diverse systems of mating. Genetics, 31, 39-59.

WRIGHT, s. 1965. The interpretation of population structure by $F$-statistics with special regard to systems of mating. Evolution, 19, 395-420.

WRIGHT, s. 1978. Evolution and the Genetics of Populations, Vol. 4. Variability Within and Among Natural Populations. University of Chicago Press, Chicago.

Young, A. G. 1988. The ecological significance of the edge effect in a fragmented forest landscape. M.Sc. Thesis, University of Auckland.

Appendix Ia Allele frequencies, genetic variation and $G$-tests for allele frequency differences at 17 loci for $A$. saccharum patch populations $(\mathrm{a}-\mathrm{h})$

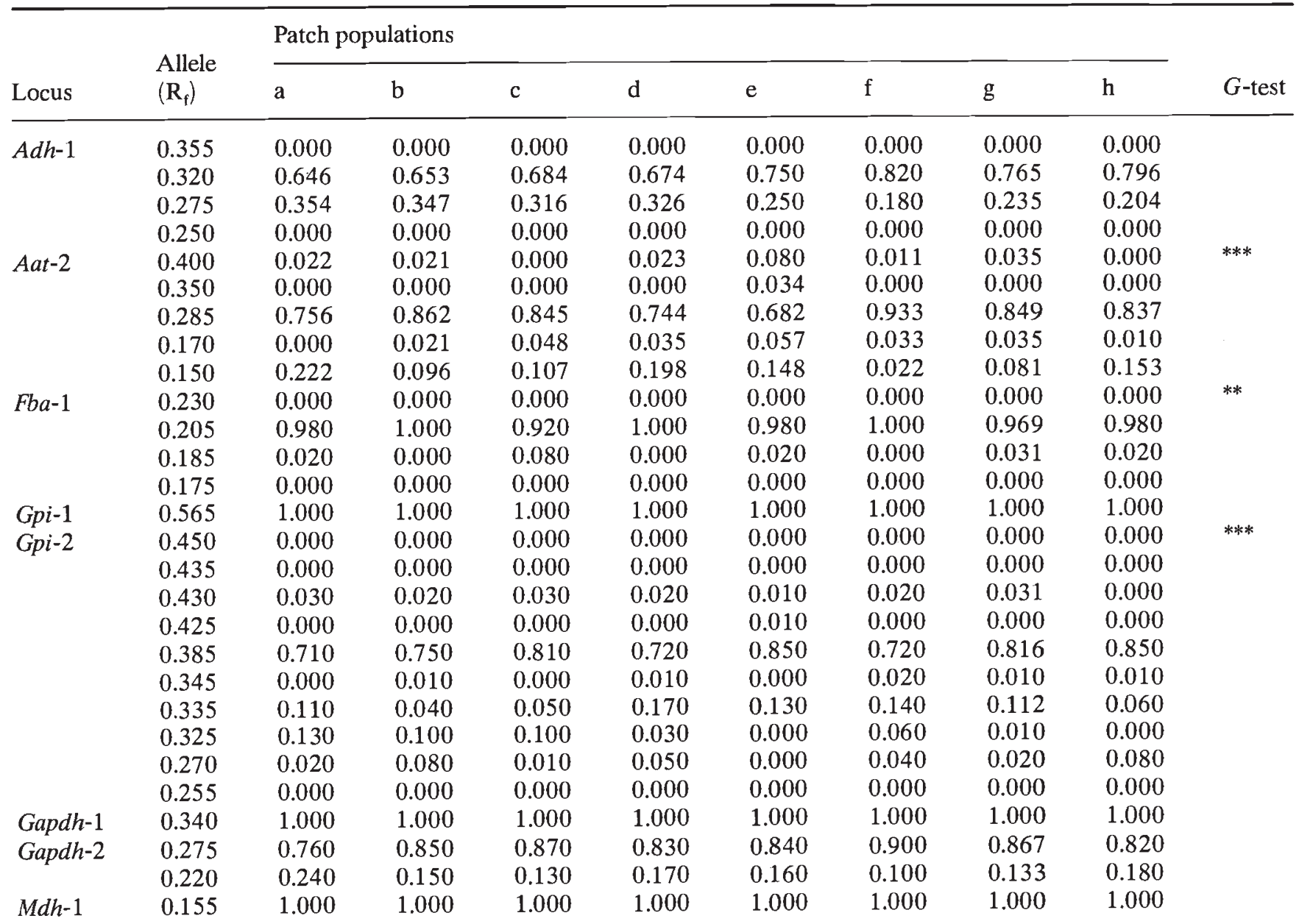


Appendix la Continued

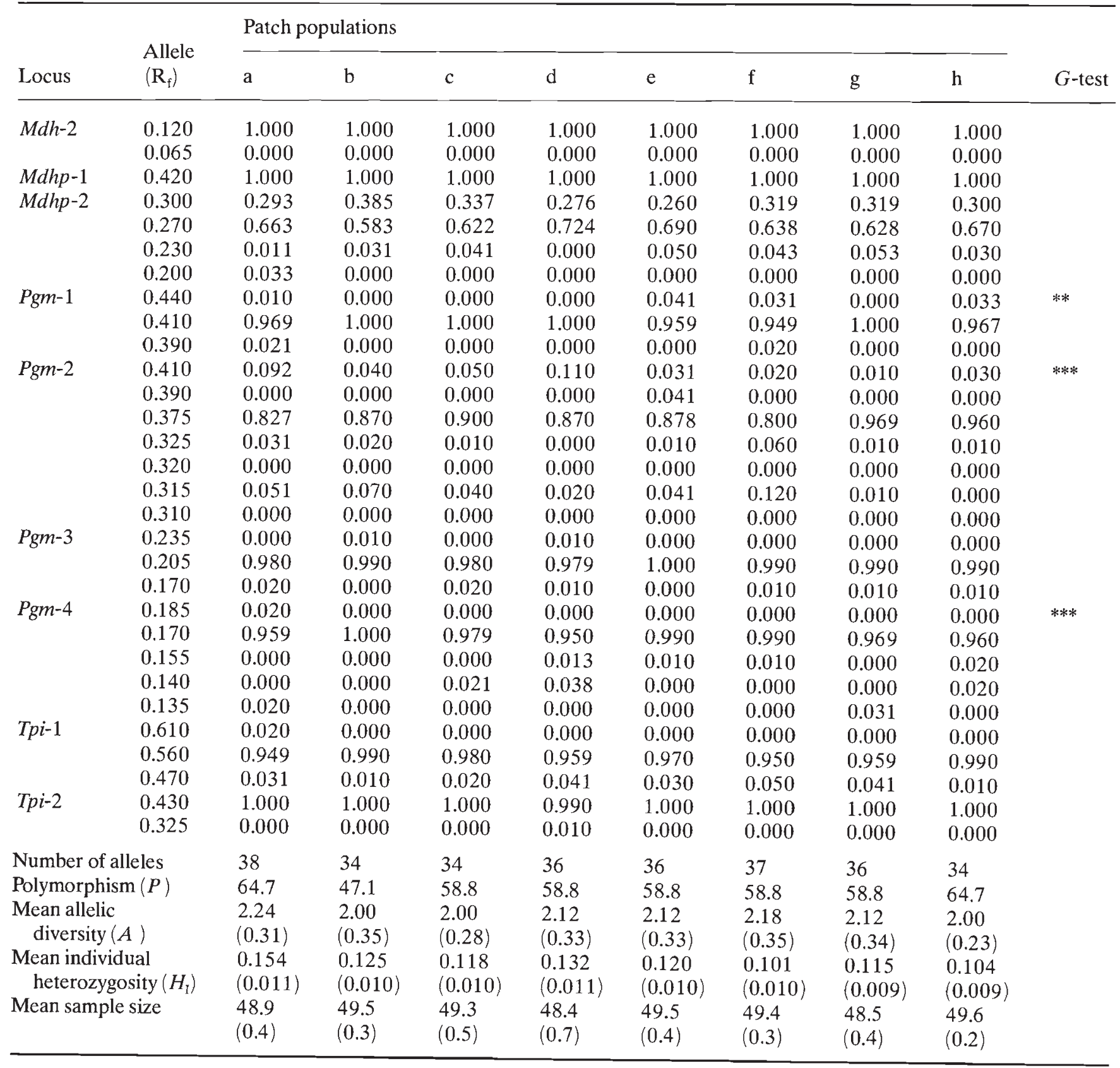

() Standard error. ${ }^{* *} p<0.01,{ }^{* * *} p<0.001$ difference in allele frequencies among populations. 
Appendix Ib Allele frequencies, genetic variation and $G$-tests for allele frequency differences at 17 loci for $A$. saccharum control populations $(\mathrm{A}-\mathrm{H})$

\begin{tabular}{|c|c|c|c|c|c|c|c|c|c|c|}
\hline \multirow[b]{2}{*}{ Locus } & \multirow{2}{*}{$\begin{array}{l}\text { Allele } \\
\left(\mathbf{R}_{\mathrm{f}}\right)\end{array}$} & \multicolumn{8}{|c|}{ Control populations } & \multirow[b]{2}{*}{$G$-test } \\
\hline & & $\mathrm{A}$ & B & $\mathrm{C}$ & $\mathrm{D}$ & $\mathrm{E}$ & $F$ & G & $\mathrm{H}$ & \\
\hline \multirow[t]{4}{*}{$A d h-1$} & 0.355 & 0.000 & 0.000 & 0.000 & 0.000 & 0.000 & 0.010 & 0.000 & 0.000 & \\
\hline & 0.320 & 0.765 & 0.800 & 0.750 & 0.760 & 0.750 & 0.800 & 0.750 & 0.755 & \\
\hline & 0.275 & 0.235 & 0.200 & 0.250 & 0.240 & 0.250 & 0.180 & 0.250 & 0.245 & \\
\hline & 0.250 & 0.000 & 0.000 & 0.000 & 0.000 & 0.000 & 0.010 & 0.000 & 0.000 & \\
\hline \multirow[t]{5}{*}{ Aat -2} & 0.400 & 0.020 & 0.011 & 0.011 & 0.036 & 0.000 & 0.000 & 0.000 & 0.000 & $* *$ \\
\hline & 0.350 & 0.000 & 0.011 & 0.000 & 0.000 & 0.000 & 0.000 & 0.000 & 0.000 & \\
\hline & 0.285 & 0.745 & 0.875 & 0.837 & 0.893 & 0.770 & 0.859 & 0.875 & 0.841 & \\
\hline & 0.170 & 0.000 & 0.023 & 0.000 & 0.000 & 0.020 & 0.026 & 0.000 & 0.000 & \\
\hline & 0.150 & 0.235 & 0.080 & 0.152 & 0.071 & 0.210 & 0.115 & 0.125 & 0.159 & \\
\hline \multirow[t]{4}{*}{$F b a-1$} & 0.230 & 0.000 & 0.000 & 0.000 & 0.000 & 0.000 & 0.000 & 0.000 & 0.010 & \\
\hline & 0.205 & 1.000 & 1.000 & 1.000 & 1.000 & 1.000 & 0.990 & 1.000 & 0.990 & \\
\hline & 0.185 & 0.000 & 0.000 & 0.000 & 0.000 & 0.000 & 0.000 & 0.000 & 0.000 & \\
\hline & 0.175 & 0.000 & 0.000 & 0.000 & 0.000 & 0.000 & 0.010 & 0.000 & 0.000 & \\
\hline$G p i-1$ & 0.565 & 1.000 & 1.000 & 1.000 & 1.000 & 1.000 & 1.000 & 1.000 & 1.000 & \\
\hline \multirow[t]{10}{*}{ Gpi-2 } & 0.450 & 0.000 & 0.000 & 0.000 & 0.000 & 0.000 & 0.030 & 0.000 & 0.000 & \\
\hline & 0.435 & 0.000 & 0.000 & 0.000 & 0.000 & 0.000 & 0.010 & 0.010 & 0.000 & \\
\hline & 0.430 & 0.060 & 0.010 & 0.020 & 0.030 & 0.070 & 0.060 & 0.050 & 0.030 & \\
\hline & 0.425 & 0.000 & 0.000 & 0.000 & 0.000 & 0.000 & 0.000 & 0.000 & 0.000 & \\
\hline & 0.385 & 0.790 & 0.830 & 0.790 & 0.830 & 0.820 & 0.710 & 0.760 & 0.760 & \\
\hline & 0.345 & 0.010 & 0.000 & 0.010 & 0.020 & 0.000 & 0.000 & 0.000 & 0.000 & \\
\hline & 0.335 & 0.060 & 0.100 & 0.100 & 0.090 & 0.070 & 0.080 & 0.090 & 0.050 & \\
\hline & 0.325 & 0.010 & 0.010 & 0.000 & 0.000 & 0.020 & 0.030 & 0.060 & 0.070 & \\
\hline & 0.270 & 0.070 & 0.050 & 0.080 & 0.030 & 0.020 & 0.070 & 0.020 & 0.090 & \\
\hline & 0.255 & 0.000 & 0.000 & 0.000 & 0.000 & 0.000 & 0.010 & 0.010 & 0.000 & \\
\hline Gapdh-1 & 0.340 & 1.000 & 1.000 & 1.000 & 1.000 & 1.000 & 1.000 & 1.000 & 1.000 & \\
\hline \multirow[t]{2}{*}{ Gapdh-2 } & 0.275 & 0.810 & 0.880 & 0.930 & 0.900 & 0.930 & 0.840 & 0.830 & 0.920 & \\
\hline & 0.220 & 0.190 & 0.120 & 0.070 & 0.100 & 0.070 & 0.160 & 0.170 & 0.080 & \\
\hline$M d h-1$ & 0.155 & 1.000 & 1.000 & 1.000 & 1.000 & 1.000 & 1.000 & 1.000 & 1.000 & \\
\hline \multirow{2}{*}{$M d h-2$} & 0.120 & 0.990 & 1.000 & 1.000 & 1.000 & 1.000 & 1.000 & 1.000 & 1.000 & \\
\hline & 0.065 & 0.010 & 0.000 & 0.000 & 0.000 & 0.000 & 0.000 & 0.000 & 0.000 & \\
\hline$M d h p-1$ & 0.420 & 1.000 & 1.000 & 1.000 & 1.000 & 1.000 & 1.000 & 1.000 & 1.000 & \\
\hline \multirow[t]{4}{*}{$M d h p-2$} & 0.300 & 0.204 & 0.293 & 0.234 & 0.337 & 0.290 & 0.195 & 0.411 & 0.327 & $* * *$ \\
\hline & 0.270 & 0.735 & 0.674 & 0.766 & 0.531 & 0.680 & 0.683 & 0.589 & 0.653 & \\
\hline & 0.230 & 0.061 & 0.033 & 0.000 & 0.133 & 0.030 & 0.110 & 0.000 & 0.020 & \\
\hline & 0.200 & 0.000 & 0.000 & 0.000 & 0.000 & 0.000 & 0.012 & 0.000 & 0.000 & \\
\hline \multirow[t]{3}{*}{$P g m-1$} & 0.440 & 0.000 & 0.000 & 0.000 & 0.020 & 0.000 & 0.010 & 0.021 & 0.020 & \\
\hline & 0.410 & 1.000 & 1.000 & 1.000 & 0.980 & 1.000 & 0.990 & 0.957 & 0.980 & \\
\hline & 0.390 & 0.000 & 0.000 & 0.000 & 0.000 & 0.000 & 0.000 & 0.021 & 0.000 & \\
\hline \multirow[t]{7}{*}{ Pgm-2 } & 0.410 & 0.100 & 0.051 & 0.082 & 0.090 & 0.000 & 0.031 & 0.042 & 0.000 & $* * *$ \\
\hline & 0.390 & 0.000 & 0.000 & 0.000 & 0.010 & 0.000 & 0.000 & 0.000 & 0.000 & \\
\hline & 0.375 & 0.880 & 0.786 & 0.898 & 0.850 & 0.930 & 0.898 & 0.844 & 0.950 & \\
\hline & 0.325 & 0.010 & 0.000 & 0.000 & 0.000 & 0.050 & 0.020 & 0.073 & 0.040 & \\
\hline & 0.320 & 0.000 & 0.000 & 0.000 & 0.000 & 0.010 & 0.000 & 0.000 & 0.000 & \\
\hline & 0.315 & 0.010 & 0.163 & 0.020 & 0.050 & 0.010 & 0.051 & 0.031 & 0.010 & \\
\hline & 0.310 & 0.000 & 0.000 & 0.000 & 0.000 & 0.000 & 0.000 & 0.010 & 0.000 & \\
\hline \multirow[t]{3}{*}{ Pgm-3 } & 0.235 & 0.000 & 0.020 & 0.000 & 0.010 & 0.030 & 0.000 & 0.000 & 0.010 & \\
\hline & 0.205 & 0.980 & 0.970 & 0.980 & 0.950 & 0.970 & 1.000 & 0.978 & 0.990 & \\
\hline & 0.170 & 0.020 & 0.010 & 0.020 & 0.040 & 0.000 & 0.000 & 0.022 & 0.000 & \\
\hline \multirow[t]{5}{*}{ Pgm-4 } & 0.185 & 0.000 & 0.000 & 0.000 & 0.000 & 0.000 & 0.053 & 0.023 & 0.000 & $* * *$ \\
\hline & 0.170 & 0.990 & 0.960 & 0.969 & 1.000 & 1.000 & 0.894 & 0.955 & 0.980 & \\
\hline & 0.155 & 0.000 & 0.000 & 0.000 & 0.000 & 0.000 & 0.000 & 0.011 & 0.020 & \\
\hline & 0.140 & 0.010 & 0.040 & 0.031 & 0.000 & 0.000 & 0.053 & 0.000 & 0.000 & \\
\hline & 0.135 & 0.000 & 0.000 & 0.000 & 0.000 & 0.000 & 0.000 & 0.011 & 0.000 & \\
\hline
\end{tabular}


Appendix Ib Continued

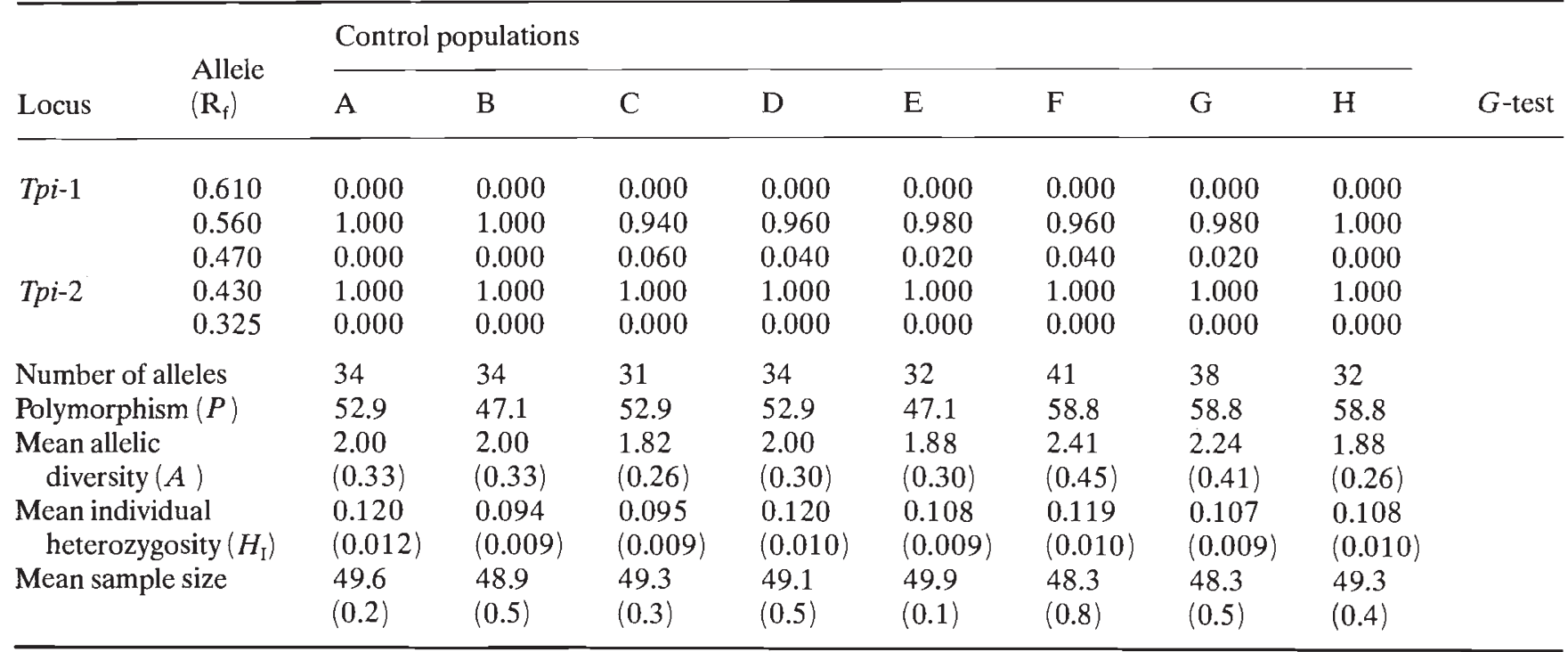

() Standard error. ${ }^{* *} p<0.01,{ }^{* * *} p<0.001$ difference in allele frequencies among populations.

Appendix IIa Inbreeding coefficients $\left(F_{\text {IS }}\right)$ and fixation coefficients $\left(F_{\text {ST }}\right)$ for $A$. saccharum patch populations (a-h)

\begin{tabular}{|c|c|c|c|c|c|c|c|c|c|}
\hline \multirow[b]{2}{*}{ Locus } & \multicolumn{8}{|c|}{$F_{\text {IS }}$ patch populations } & \multirow[b]{2}{*}{$F_{\mathrm{ST}}$} \\
\hline & $\mathrm{a}$ & $\mathrm{b}$ & c & $\mathrm{d}$ & $\mathrm{e}$ & $\mathrm{f}$ & $\mathrm{g}$ & $\mathrm{h}$ & \\
\hline$A d h-1$ & -0.002 & 0.189 & 0.009 & -0.187 & 0.093 & 0.322 & 0.148 & -0.005 & 0.020 \\
\hline Aat -2 & 0.062 & 0.054 & 0.387 & 0.025 & 0.050 & -0.049 & -0.118 & 0.261 & 0.032 \\
\hline$F b a-1$ & 1.000 & - & 0.185 & - & 1.000 & - & -0.032 & 1.000 & 0.029 \\
\hline Gpi-2 & -0.074 & -0.050 & -0.029 & -0.114 & 0.002 & 0.167 & -0.150 & 0.102 & 0.022 \\
\hline Gapdh-2 & -0.096 & -0.020 & 0.027 & 0.079 & -0.190 & 0.111 & -0.153 & -0.084 & 0.011 \\
\hline$M d h p-4$ & -0.149 & -0.143 & 0.015 & $0.438^{*}$ & -0.014 & 0.086 & 0.024 & - & 0.007 \\
\hline$P g m-1$ & 0.658 & - & - & - & $1.000^{*}$ & 0.376 & - & -0.034 & 0.020 \\
\hline$P g m-2$ & -0.004 & -0.101 & -0.076 & -0.127 & 0.276 & 0.180 & -0.021 & -0.034 & 0.027 \\
\hline$P g m-3$ & -0.021 & -0.010 & -0.020 & -0.016 & - & -0.010 & -0.010 & -0.010 & 0.005 \\
\hline$P g m-4$ & 0.484 & - & 1.000 & 0.479 & -0.010 & -0.011 & -0.032 & 0.485 & 0.014 \\
\hline Tpi-1 & 0.376 & -0.010 & -0.020 & -0.043 & -0.031 & 0.368 & -0.043 & -0.010 & 0.008 \\
\hline$T p i-2$ & - & - & - & -0.010 & - & - & - & - & 0.009 \\
\hline Mean & 0.013 & -0.011 & 0.068 & 0.034 & 0.079 & 0.172 & -0.029 & 0.075 & 0.019 \\
\hline
\end{tabular}

$F_{\mathrm{IS}}$ and $F_{\mathrm{ST}}$ are weighted by expected heterozygosity. ${ }^{*} p<0.05$ deviation from Hardy-Weinberg equilibrium. 
Appendix IIb Inbreeding coefficients $\left(F_{\mathrm{IS}}\right)$ and fixation coefficients $\left(F_{\mathrm{ST}}\right)$ for $A$. saccharum control populations $(\mathrm{A}-\mathrm{H})$

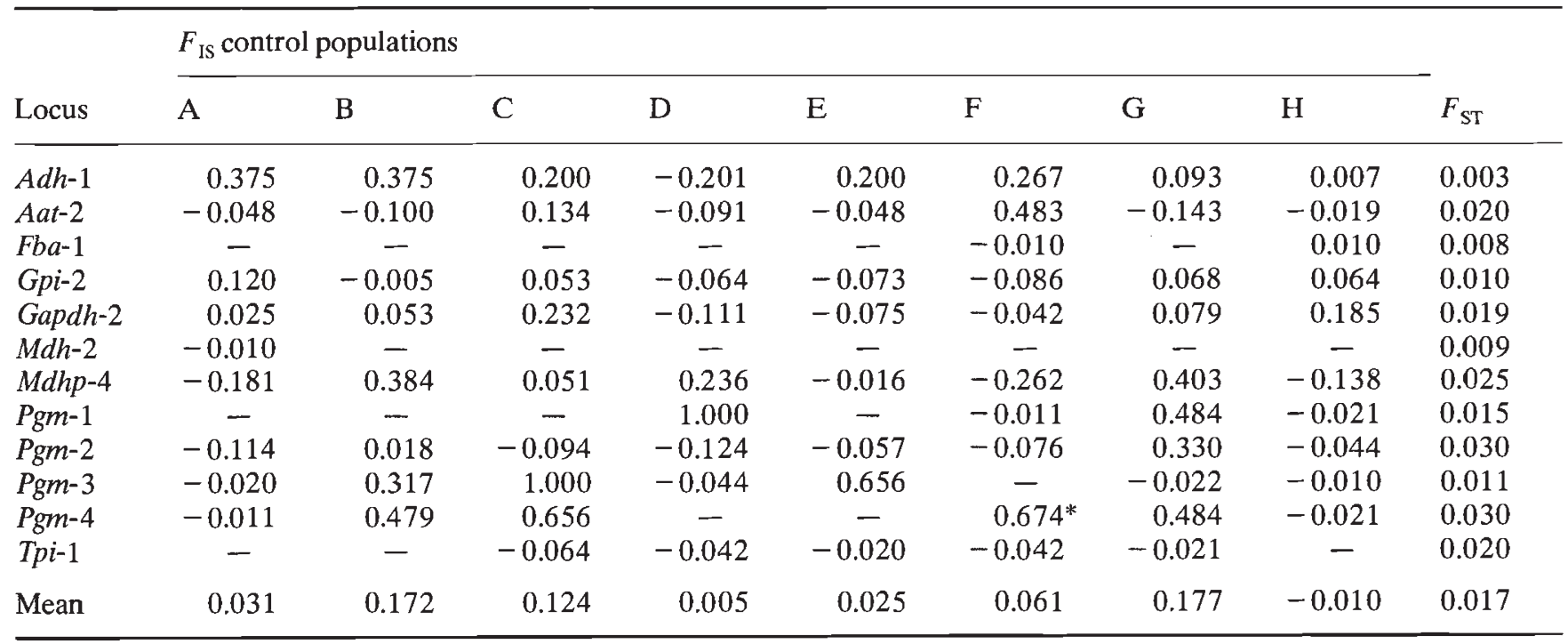

$F_{\mathrm{IS}}$ and $F_{\mathrm{ST}}$ are weighted by expected heterozygosity. ${ }^{*} p<0.05$ deviation from Hardy-Weinberg equilibrium. 